Ks. Jerzy Woźniak CM

\title{
KONFERENCJA SYRIOLOGICZNA W LEJDZIE (1985)
}

W dniach 30-31 sierpnia 1985 roku jedyny na świecie Instytut Peszity (Peshitta Institute) w Lejdzie zorganizował konferencję naukową poświęconą najstarszemu syryjskiemu przekładowi Starego Testamentu zwanemu Peszito. W konferencji wzięło udział około 25 uczonych z całego świata, współpracowników Instytutu pracujących nad wydaniem krytycznym ST jako Vetus Testamentum Syriace. Z Polski wziął udział ks. Jerzy Woźniak z Krakowa.

Zasługą Instytutu Peszity jest organizowanie krytycznego wydania tekstu syryjskiego ST. Od roku 1959 na czele tegoż Instytutu stał Prof. P. A. H. de Boer, a obecnie od roku 1981 kieruje nim prof. J. Mulder. Dotychczas pod auspicjami Instytutu wydano następujące księgi ST Rodzaju, Wyjścia, Joba, Sędziów, Samuela, Królewskie, Psalmów, Tobiasza, Przysłów, Mądrości, Pieśni nad Pieśniami, Eklezjastesa, Dwunastu Proroków Mniejszych, Daniela.

Dnia 30 sierpnia 1985 r. sesji przedpołudniowej przewodniczył profesor z Edynburga W. M. Mc Kane, a referaty wygłosili: S. P. Brock z Oxfordu, M. P. Weitzman z Londynu i J. Muldner z Lejdy.

Prof. S. Brock, profesor języków semickich w Oxfordzie, który przygotował do druku tekst Peszity Izajasza, podzielił się uwagami na temat historii tekstu Izajasza. Prelegent wyróżnił sześć grup manuskryptów syryjskich Izajasza oraz ukazał systemy podzialów tychże grup.

$\mathrm{Dz}$ M. Weitzman z Londynu przedstawił referat pt. „Oryginalność rękopisu MS. 9a 1". Mówca zebrał ciekawsze rozwiązania tekstu syryjskiego w porównaniu z tekstem masoreckim i Septuagintą oraz niektórymi rękopisami nestoriańskimi.

W miejsce zgłoszonego referatu M. Goshen-Gottsteina z Jerozolimy a nieobecnego Dyrektor Instytutu J. M uld e r przedstawił referat na temat Peszity księgi Ezechiela, który wygłosił dzień wcześniej w Louvain podczas Dni Biblijnych. Prelegent w oparciu o swoje doświadczenia nad księgą Ezechiela omówił ciekawsze wersety tejże księgi, a zwłaszcza dodatki i zmiany w rękopisach syryjskich ukazujące różnice w interpretacji względem tekstu masoreckiego.

Sesji popołudniowej przewodniczył badacz Septuaginty, światowej sławy profesor z Toronto J. W. Wevers, a referaty wyglosili - A. Gelston, A. van der Kooij, M. D. Koster i J. Cook.

A. Gelston, ksiądz anglikański z Wielkiej Brytanii omówił niektóre lekcje Peszity do Dwunastu Proroków Mniejszych; przeanalizował 39 ciekawszych fragmentów oraz wskazał na zamierzone usterki tekstu i różnice wobec tekstu masoreckiego.

Dr A. van der Kooij z Utrechtu zapoznał uczestników ze znaczeniem manuskryptu 5b 1 dla Peszity księgi Rodzaju.

Następnie Dr M. D. Koster, proboszcz katolicki z Hengelo i wydawca krytycznego tekstu Peszity do Księgi Wyjścia, zaprezentował rozwój tekstu Peszity w świetle najnowszych publikacji. Ostatni zaś referat pierwszego dnia wygłosił Dr J. Cook z Stellenbosh, który pracuje nad konkordacją syryjską do ST. W swej prelekcji omówił kompozycje Peszity do Pięcioksięgu.

Sesji przedpołudniowej drugiego dnia przewodniczył profesor A. Albrektson $z$ Lunda a referaty wyglosili: R. J. Owens, J. Mulder, K. D. Jenner i P. B. Dirksen.

R. J. O wens z USA przedstawił referat na temat roli Afrahata jako świadka wczesnego tekstu Peszity w Pięcioksięgu, zwracając uwagę na cytaty z ksiąg: Kapłańskiej, Liczb, Powtórzonego Prawa użyte przez Afrahata 
w słynnych jego Demonstrationes. R. J. Owens skoncentrował się głównie na księdze Kapłańskiej i jest zdania, że cytaty z księgi Kapłańskiej nie dają jasnego świadectwa potwierdzającego tekst Peszity. Na przykład zaprezentowane fragmenty $\mathrm{z} \mathrm{Kpl} 9,24 ; 10,1-4 ; 11,2 ; 13,45 ; 13,46$ sa różne od Peszity na przykładzie tekstu ambrozjańskiego, aczkolwiek można znaleźć także teksty zgodne z Peszitą: np. Kpł 15, 5; 19, 17; 22, 31. J. Mulder przedstawił realizację programu krytycznego wydanie Peszity ST i plany na przyszłość. Oznajmił, że w druku jest tekst Izajasza opracowany przez S. Brocka z Oxfordu oraz tekst Ezechiela przygotowany przez niego samego. W przygotowaniu są również teksty ksiąg Kpł, Lb, Ppr opracowane przez R. J. Owensa i Dr Haymana.

Dr K. D. J e nner z Lejdy omówił ważność rękopisu - Paris Syr 341/8a 1 dla krytyki tekstu Peszity.

Jako ostatni prelegent wystąpił Dr P. B. Dirksen, pracownik Instytutu Peszity, który omówił problem rozwoju wariantów w starożytnych rękopisach. Dirksen wykorzystał rezultaty swojej rozprawy pt. The Transmission of the Text in the Peshitta Manuscripts of the Book Judges, Leiden 1971. Prelegent ograniczył się do księgi Sędziów i wskazał na błędy i różnice tekstualne w rękopisach Peszity księgi Sędziów.

Podsumowując konferencję syriologiczną, pierwszą tego typu zorganizowaną przez Instytut Peszity, trzeba stwierdzic wysoki poziom naukowy prelekcji i dyskusji prowadzonych przez najlepszych specjalistów. Materiały z konferencji ukażą się w 1986 roku jako IV tom serii „Monographs of the Peshitta Institute" w Lejdzie.

Kraków

KS. JERZY WOŹNIAK CM

\section{Ks. Bernard Wodecki SVD}

\section{DNI JUDAISTYCZNE W PIENIĘŻNIE}

W dniach 16-17 kwietnia $1986 \mathrm{r}$. odbyły się w Wyższym Misyjnym Seminarium Duchownym Księży Werbistów w Pieniężnie na Warmii Dní Judaistyczne. Spotkanie z Żdami polskimi, starszymi naszymi braćmi (jak nazwał żydów papież Jan Paweł II) zorganizowało i przeprowadziło wspomniane Seminarium w ramach „Pieniężniańskich Spotkań z Religiami" i było drugim z tej serii, po zorganizowanym w r. 1985 Dniu Muzułmańskim (Spotkanie z Islamem).

Dni Judaistyczne otwarł uroczystą Mszą św. miejscowy ordynariusz, ks.: biskup dr Edmund Piszcz przybyły z Olsztyna, który wygłosił także stosowną homilię, a po śniadaniu w asyście przełożonych polskiej prowincji SVD i Seminarium, wykładowców, licznych przedstawicieli Żydów polskich $\mathrm{i}$ innych przybyłych $\mathrm{z}$ całego kraju gości dokonał otwarcia wystawy judaistycznej w pomieszczeniach miejscowego Iuzeum Etnologiczno-misjologicznego.

Dni Judaistyczne, pierwsze tego rodzaju w Polsce, wzbudziły żywe zainteresowanie i zgromadziły ponad 200 uczestników.

Słowo wstepne wygłosił ks. dr E. Śliwka SVD, dyrektor miejscowego Muzeum i wykładowca Seminarium. Podkreślił on szczególnie, że odby- 